\title{
Quantifying the rate of subsistence wood harvesting from a tropical rainforest in Kenya
}

\author{
Christopher Amutabi Kefa, Mark Lung, Anton Espira and Andrew J. Gregory
}

\begin{abstract}
One of the major threats to tropical forests throughout the world is the frequency and intensity with which local people use forests for subsistence. Kakamega Forest in Kenya is one such forest, in which fuelwood harvest is a primary use. The Kenya Forest Service and Kenya Wildlife Service have tried to regulate subsistence harvesting in this forest. However, high human population density (c. 542 people per $\mathrm{km}^{2}$ ) and extreme poverty leave local people little choice but to use forest resources to survive. We investigated patterns of wood use by people across Kakamega Forest. Our results indicate that wood harvesters prefer indigenous as opposed to non-indigenous wood, as the former sells for a premium price. Harungana madagascariensis and Psidium guajava were the most harvested indigenous and non-indigenous woods, respectively. Our data suggest that because market economies seem to drive forest use, perhaps they can be used to incentivize forest conservation. Proper integration of economic forest conservation interventions, economic diversification, and effective forest management are needed to protect Kakamega Forest.
\end{abstract}

Keywords Kakamega Forest, Kenya, market economy, subsistence harvest, wood harvest

G lobally, rainforests are in decline as a result of an increase in anthropogenic activities (Tscharntke et al. 2010). At the turn of the 2oth century lowland tropical rainforest cover across Kenya was c. 240,00o ha (Freund, 2005) but following severe deforestation and fragmentation, Kakamega Forest in western Kenya is the only remaining lowland tropical rainforest in the country. It covers 24,000 ha, with only 10,000 ha $(42 \%)$ of indigenous forest remaining (Mitchell, 2004). Kakamega forest has high biodiversity, including rare and endemic species (KIFCON, 1994), and is the easternmost remnant of the Guineo-Congolian rainforest, which once spanned equatorial Africa (Kokwaro, 1988).

A common theme throughout the developing world is of a high density of poor people living adjacent to tropical forests who rely on subsistence harvesting from these forests (Myers, 1992). This is also true of Kakamega Forest, which

Christopher Amutabi Kefa and Andrew J. Gregory (Corresponding author) School of Earth, Environment and Society, Bowling Green State University, Bowling Green, Ohio, USA. E-mail agregor@bgsu.edu

Mark Lung and Anton Espira Eco2librium Corp., Kakamega, Kenya, and Boise, Idaho, USA

Received 30 March 2016. Revision requested 27 June 2016.

Accepted 5 September 2016. First published online 17 April 2017. lies amidst one of the most densely populated rural areas of Kenya (542 people per $\mathrm{km}^{2}$; KNBS, 2015); 52\% of the population live on $<$ USD 1 per day (KNBS, 2009). Consequently, people have little choice but to rely on the harvesting of forest products for food, income and fuel (Wambua, 2008).

Kakamega Forest is managed by two semi-autonomous government agencies: the Kenya Forest Service, which collaborates with local Community Forest Associations to manage $196 \mathrm{~km}^{2}$ (c. 82\%) of the forest, and Kenya Wildlife Service, which manages $44 \mathrm{~km}^{2}$ (c. 18\%). In 1991 the two Services entered into a memorandum of understanding for management of forests throughout Kenya (Guthiga \& Mburu, 2006). Within its jurisdiction, the Kenya Forest Service incentivizes conservation of Kakamega Forest by allowing people to legally harvest forest products upon the purchase of a permit, whereas the Kenya Wildlife Service prohibits all forms of harvest. Penalties for offenders in the area managed by the Kenya Wildlife Service are severe (Guthiga \& Mburu, 2006; Wildlife Conservation \& Management Act, 2013).

Nevertheless, illegal activities such as logging, charcoal burning and hunting occur throughout Kakamega Forest (Bleher et al., 2006). There is, however, little information about how much and at what rate local communities are harvesting forest resources, either legally or illegally. The objectives of this study were fourfold: (1) quantify the rate and amount of wood harvested from Kakamega Forest; (2) assess differences in wood harvest between the areas managed by the two Services; (3) determine which, if any, wood species are preferentially harvested; and (4) assess economic drivers of wood harvest, and how far from the forest the harvested wood is used.

This project was conducted in collaboration with local people and the Kenyan conservation corporation Ecozlibrium. Ecozlibrium is a for-profit company that uses business solutions to solve social and environmental problems (Gao et al., 2015). From March to August 2015, we walked along forest edges and forest trails and randomly sampled women and girls who were bearing fuelwood, enquiring if we could weigh their wood bundles (Fig. 1). Wood harvesting from the forest is the primary source of cooking fuel for $>90 \%$ of people living near Kakamega Forest and is typically collected by women and young girls (Kiefer \& Bussmann, 2008). We weighed head-load bundles at 24 locations (21 and three in the Kenya Forest Service and Kenya Wildlife Service jurisdictions, respectively) and recorded the latitude and longitude, and date and time of measurements for each location. Sampling was randomized so that the 


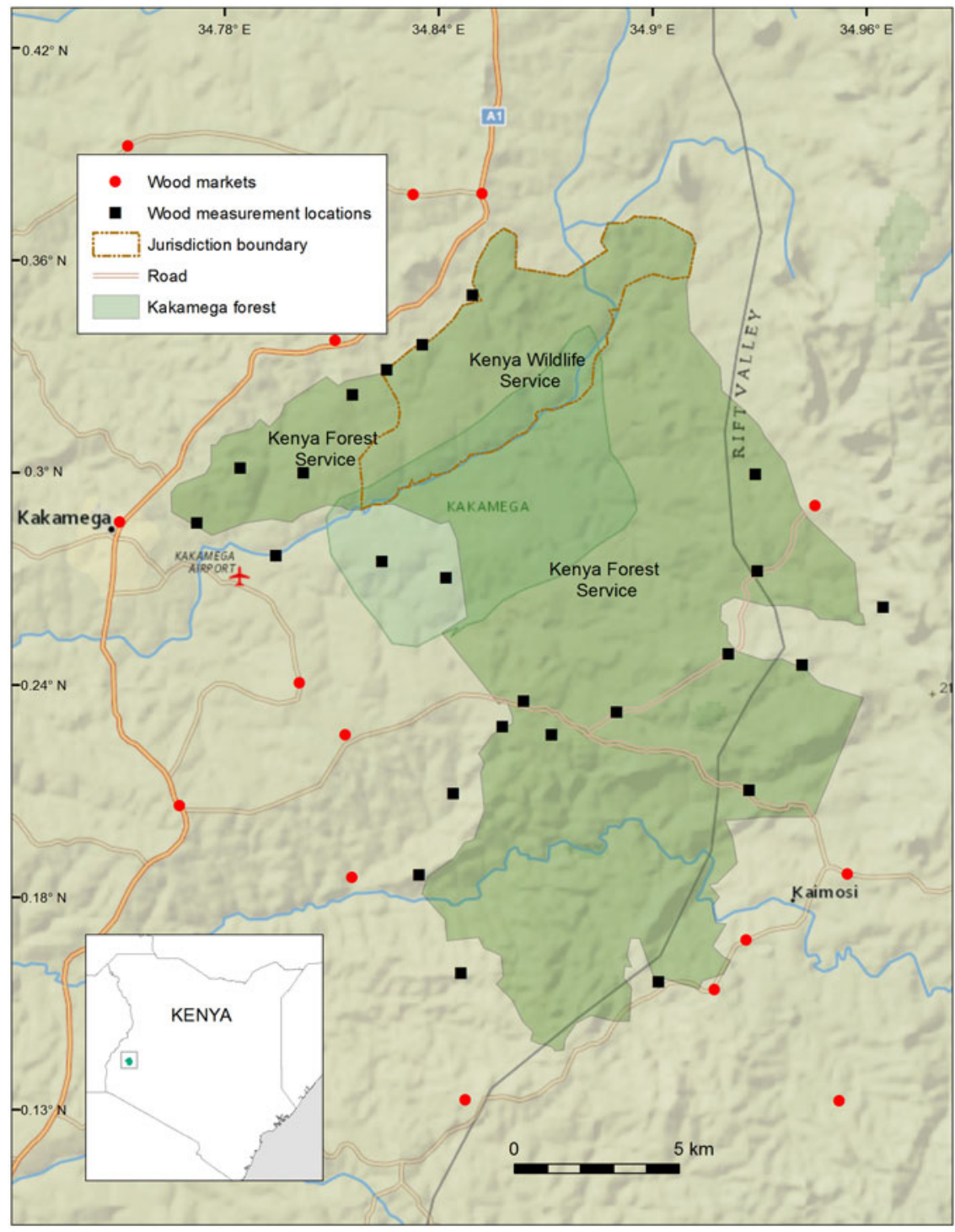

FIG. 1 Kakamega Forest, Kenya, showing the locations where harvested wood was collected and of markets where wood was sold.
Kenya Forest Service and Kenya Wildlife Service areas would be sampled proportionally. We varied the time and locations of measurements, to reduce avoidance bias. Avoidance of researchers is common in wood harvest studies because many harvesters lack permits, harvest restricted species or cut wood, and the permits only allow harvesters to gather already felled wood from non-indigenous species (Guthiga \& Mburu, 2006).

For each head load we recorded wood mass, \% cut wood (as opposed to already felled wood), \% of wood from indigenous species, species, and bundle diameter, length and circumference. The field assistant was a trained forester and identified species based on local knowledge and the use of a field guide (Dalitz et al., 2011). We measured headload mass by weighing wood harvesters with and without their bundles, subtracting body weight. To reduce interobserver bias in estimation of \% cut and \% indigenous wood, we stratified percentages in six equally distributed bins and recorded the median percentile of each bin. While we measured wood bundles we also interviewed harvesters, requesting information about (1) age, (2) family size, (3) number of wood collection trips per week, and (4) home village (from which we were able to approximate the distances travelled to harvest wood).

We followed a subset of measured wood bundles from field sites to households or wood markets, to interview harvesters and wood buyers, asking (1) how much they charged for wood; (2) how they transported wood to and from markets; and (3) if a harvest or selling permit was required. All descriptive statistics were calculated using $R$ v. 3.3.o (R Development Core Team, 2015). To assess differences in wood harvesting (number of trips per week, wood mass, $\%$ cut wood, $\%$ indigenous wood, and wood diameter) between the Kenya Forest and Kenya Wildlife Service jurisdictions we used a multivariate analysis of variance, calculated with SAS 9.4 (SAS Institute Inc., Cary, USA). 
TABLE 1 Results of surveys of the head bundles of wood carried by wood harvesters collecting from the jurisdictions of the Kenya Forest Service and Kenya Wildlife Service in Kakamega Forest (Fig. 1), Kenya, with $F$ and P values from a multivariate analysis.

\begin{tabular}{lllrr}
\hline Variable $^{1}$ & Kenya Forest Service & Kenya Wildlife Service & $F$ & P \\
\hline Number of head bundles & 235 & 35 & 10.31 & $0.002^{\star}$ \\
Wood mass (kg) & $30 \pm$ SD 8 & $22 \pm$ SD 4 & 92.38 & $<0.0001^{*}$ \\
Distance travelled (m) & $3,045 \pm$ SD 1,395 & $924 \pm$ SD 1,221 & 17.55 & 8.37 \\
Median age (years) & 24 & 13 & 5.49 & $0.0001^{*}$ \\
Trips per week & $3 \pm$ SD 1 & $2 \pm$ SD 1 & 0.14 & $0.0199^{*}$ \\
\% cut wood & 23.5 & 4.5 & 11.36 & 0.7070 \\
Family size (median) & 5.5 & 6 & 0.85 & $0.0009^{*}$ \\
\% indigenous wood & 68 & 95 & 0.357 \\
Diameter (cm) & 4.8 & 5.8 & & 0.85 \\
\hline
\end{tabular}

${ }^{*} \mathrm{P} \leq 0.05$.

${ }^{1}$ Wood mass, mean head-bundle mass; Distance travelled, mean distance travelled by harvesters to collect wood; Median age, median age of wood harvesters; Trips per week, mean number of wood collection trips per person per week; \% cut wood, estimated \% of cut wood in wood bundles by weight; Family size, median size of harvester's family; \% indigenous wood, estimated \% of indigenous wood in wood bundles by weight; Diameter, mean diameter of wood in head loads.

We measured a total of 270 head bundles, and conducted 240 interviews around and within Kakamega Forest (Fig. 1) and 63 at 12 wood markets. Mean head-load mass was $29 \pm$ SD $_{14} \mathrm{~kg}$, harvesters made a mean of $3 \pm \mathrm{SD}_{2}$ trips to the forest per week, and $99 \%$ of harvesters were females aged 6-68 years (median age $=16$ years). Eleven percent of wood harvesters were aware of the need to have a permit to harvest firewood from the Kenya Forest Service forest. People harvesting from the Kenya Forest Service jurisdiction carried heavier bundles, walked longer distances to the forest, were older, made more collection trips per week, and carried a greater percentage of cut wood and a lower percentage of indigenous wood than those harvesting from the Kenya Wildlife Service jurisdiction (Table 1; multivariate analysis of variance $\mathrm{F}(28,35)=29.36, \mathrm{P}<0.0001$; Wilk's $\Lambda=0.464)$.

We identified 47 tree species in the head loads, 34 (72\%) of which were from indigenous species. By weight the most common indigenous species harvested was Harungana madagascariensis $(15 \%$ of all indigenous species harvested; Fig. 2a), and the most common non-indigenous species harvested was the guava tree Psidium guajava (40\% of all nonindigenous wood harvested; Fig. 2b). This was consistent with the results from the wood market interviews, in which $H$. madagascariensis (25\%, by weight, of indigenous wood species) and P. guajava (33\%, by weight, of nonindigenous species) were the preferred indigenous and nonindigenous woods purchased by buyers.

Wood was transported to the markets by foot $(73.4 \%$ of sellers/transporters), motorcycle (9.4\%), tractor (9.4\%) and bicycle $(4.7 \%)$. The maximum distance that wood was transported by foot was $9 \mathrm{~km}$. When transported by motorcycle or tractor (by either harvesters or sellers), wood reaches as far as Kisumu, c. $50 \mathrm{~km}$ from the forest. At markets harvesters sell wood directly to end users or to sellers; the latter break down the bundles by species and size and collate them into new bundles. Wood from indigenous species is sold for a premium price and is in higher demand compared to wood from non-indigenous species. For example, at Lubao market a head-load bundle of wood from indigenous species sold directly by a harvester cost KES 200 (c. USD 2) whereas a head-load bundle from non-indigenous species sells for c. $25 \%$ less (KES 150, c. USD 1.5). Hotels purchased most of the wood ( $56 \%$ of buyers), followed by individuals (41\%), schools (2\%) and churches (1\%).

Our study has four key findings. Firstly, we have quantified the rate of wood harvest from the areas managed by the Kenya Wildlife Service and Kenya Forest Service in Kakamega Forest. Secondly, those harvesting wood from the Kenya Wildlife Service jurisdiction are significantly younger and make fewer trips to the forest per week, suggesting that people are attempting to avoid arrest by sending their children. Thirdly, wood from indigenous species is preferred over that of non-indigenous species, and this preference is driven by market values, with buyers paying up to $25 \%$ more for the former (from our $>20$ years of personal experience in the area, wood from the indigenous species harvested burns at a more consistent temperature, for a longer time, and has a more pleasant aroma and higher heat intensity). Fourthly, wood from Kakamega Forest is being sold in markets up to c. $50 \mathrm{~km}$ from the forest.

Fuelwood is the main product harvested from Kakamega Forest because it is a cheap source of energy for most households (Kiplagat et al., 2008). The Kenya Forest Service offers regulated extraction, under permit, of forest resources as an incentive for conservation, and as $\geq$ c. $52 \%$ of people around the forest live in extreme poverty, with limited economic opportunities, this could be an incentive for forest conservation. However, there needs to be a balance between the rate of extraction, regeneration and replacement of forest resources, and both proper management and controlled harvesting are necessary to protect the forest. 

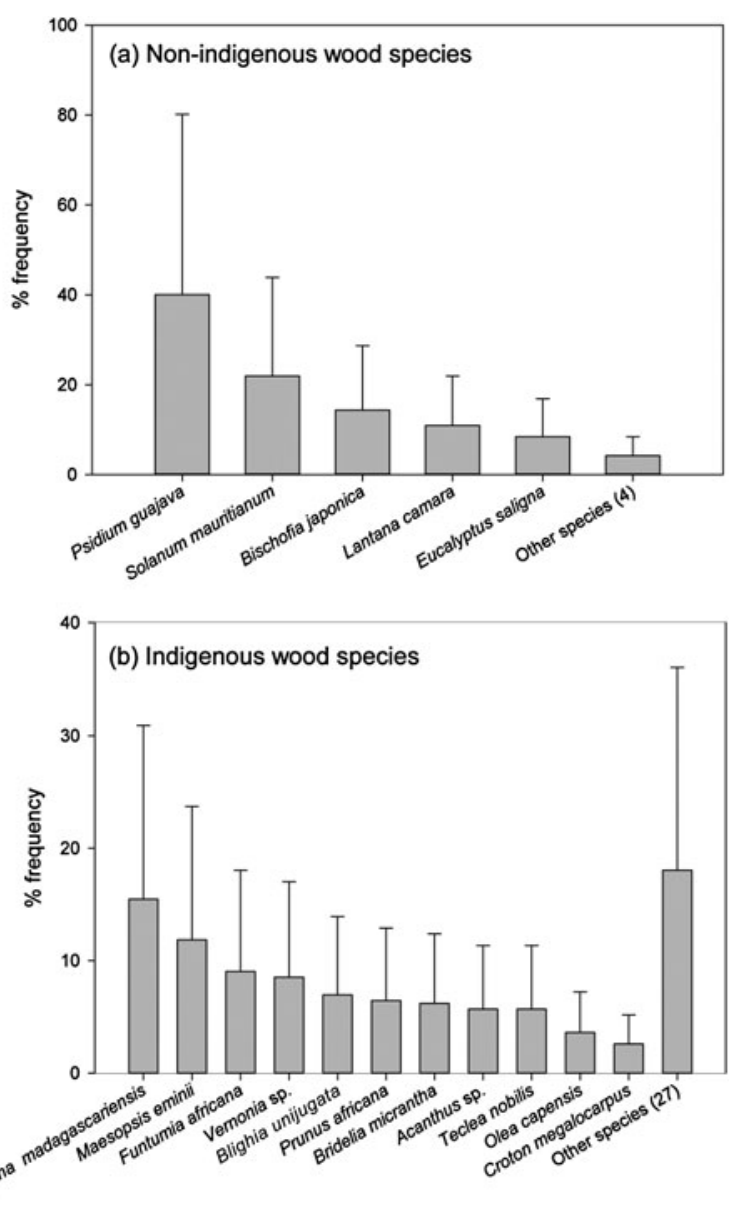

FIG. 2 Percentage frequency $( \pm S D)$ of wood from (a) indigenous and (b) non-indigenous tree species harvested from Kakamega Forest, Kenya (note the different y-axis scales).

The Kenya Wildlife Service, however, prohibits harvesting of wood and other forest products to ensure minimal disruption of ecological processes. Dead wood is crucial for forest health (Pfeifer et al., 2015), providing, for example, habitat and breeding sites for birds and invertebrates, and a substrate and nutrient source for fungi (Vrška et al., 2015), all of which are important for forest regeneration and maintenance of diversity (Travaglini et al., 2007). The area managed by the Kenya Wildlife Service has higher biodiversity than that managed by the Kenya Forest Service (Kefa, 2016), suggesting that restrictive laws and harsh penalties may be a better approach for conserving forest biodiversity.

Areas with natural forest and indigenous trees such as Kakamega Forest may be targeted for wood extraction. To complicate matters further, the people charged with enforcing wood harvesting laws are often implicated in illegal logging or harvesting activities. For example, Mabatuk \& Wesangula (2015) recently reported that KES 20 million (approximately USD 20,000) worth of sandalwood Santalum album timber was impounded while being transported in a police car by an off-duty police officer (Mabatuk \& Wesangula, 2015). Such blatant disregard for the law by those entrusted with its enforcement is perhaps the most difficult challenge to the conservation of Kenya's forests.

However, this may also suggest a way forward. As market economies seem to be driving deforestation, perhaps they could be used to incentivize forest conservation by diversifying local income, thereby reducing demand for forest resources. For example, with proper sensitization, the harvesting of invasive non-indigenous hardwood tree species, such as guava, could be encouraged, to counteract the high demand for wood from the rarer indigenous species. In addition, business solutions could be used to implement projects that create jobs, improve livelihoods and reduce demand for forest products (Lung \& Espira, 2015). Regardless, our data suggest that integration of economic forest conservation, economic diversification and effective forest management is needed to protect this forest.

\section{Acknowledgements}

Field methods were reviewed by the Bowling Green State University Human Subjects Research Board and were granted a waiver of approval on 10 March 2015, prior to the start of fieldwork. All research was conducted with the knowledge and approval of the legal governing bodies of Kenya and the Kakamega Forest, namely, Kenya National Commission for Science and Technology (Ref. no. NACOSTI/P/15/6537/4622), Kenya Forest Service (Ref. no, RESEA/1/KFS/VOL.II(25)), Kenya Wildlife Service (Ref. no. KWS/BRM/5001), the County Government of Kakamega (Ref. no. ED/12/1/169) and the State Department of Education (Kakamega County; Ref. no. WP/GA/29/17/VOL. II/2049). We thank the Kenya National Commission for Science and Technology, Kenya Forest Service and Kenya Wildlife Service for granting us permits to undertake this study and the County government of Kakamega County for approving our research permit, our collaborators at the National Museum of Kenya for administrative, logistical and technical support, the anonymous participants who spoke with us and allowed us to weigh their wood bundles, Bowling Green State University for material, financial and technical support, Dr Kefa Otiso and Genetic Research in Applied Spatial Ecology Lab members for their comments, the technicians Emma Spence, Gregory Brinkman and Nadejda Mirochnitchenko, Eco2librium staff, and in particular Herbert Imbuka, for their assistance with interviews, and two anonymous reviewers for their critiques.

\section{Author contributions}

CAK and AJG designed the project, collected and analysed the data, and wrote the article. ML and AE funded field data collection and helped with acquisition of necessary research permits from the Kenyan government. 


\section{References}

Bleher, B., Uster, D. \& Bergsdorf, T. (2006) Assessment of threat status and management effectiveness in Kakamega Forest, Kenya. In Forest Diversity and Management (eds D.L. Hawksworth \& A. T. Bull), pp. 99-117. Springer, Dordrecht, The Netherlands.

Dalitz, C., Dalitz, H., Musila, W. \& Masinde, S. (2011) Illustrated Field Guide to the Common Woody Plants of Kakamega Forest. Institut für Landschafts und Pflanzenökologie, Stuttgart, Germany.

FREUND, W.M. (2005) Effects of fragmentation and degradation of an Afrotropical rain forest on the diversity structure of leaf beetle communities (Coleoptera, Chrysomelidae). PhD thesis. University of Bonn, Bonn, Germany.

Gao, L., Jackson, S., Jeon, Y., Jung, M. \& Schaller, R. (2015) Can the Certified B Corporation Alleviate Nonprofit Constraints \& Advance the Cultural Sector? Capstone project report on innovation and the non-profit model. New York, USA.

Guthiga, P. \& Mburu, J. (2006) Local communities' incentives for forest conservation: case of Kakamega Forest in Kenya. Proceedings of the 11th Conference of the International Association for the Study of Common Property. Bali, Indonesia.

KEFA, C.A. (2016). Assessing the impacts of bioenergy extraction and human land use of the biodiversity of Kakamega Tropical Rainforest, Kenya. MSc thesis. Bowling Green State University, Bowling Green, USA.

Kiefer, S. \& Bussmann, R.W. (2008) Household energy demand and its challenges for forest management in the Kakamega area, western Kenya. Journal of Ethnobotany Research and Applications, 6, 363-371.

KifCON (Kenya Indigenous Forest Conservation) (1994) Kenya Indigenous Forest Conservation Program in Kakamega Forest. The Official Guide. Forest Department, Nairobi, Kenya.

Kiplagat, K., Mburu, J. \& Mugendi, N. (2008) Consumption of non-timber forest products (NTFPs) in Kakamega Forest, Western Kenya: accessibility, role, value and to resident rural households. A paper presented to the 2008 IASC Biennial International Conference 14-19 July 2008, University of Gloucestershire, Cheltenham, UK.

KNBS (Kenya National Bureau of Statistics) (2009) The 2009 Kenya Population and Housing Census. Kenya National Bureau of Statistics, Nairobi, Kenya.

KNBS (Kenya National Bureau of Statistics) (2015) A 2015/16 Kenya Integrated Household Budget Survey (KIHBS) - Measuring Well-Being for Sustainable Development. Status report. Kenya National Bureau of Statistics, Nairobi, Kenya.

Kokwaro, J.O. (1988) Conservation status of the Kakamega Forest in Kenya: the easternmost relic of the equatorial rain forests of Africa. Monographs in Systematic Botany of the Missouri Botanical Garden, 25, 471-489.

Lung, M. \& Espira, A. (2015) The influence of stand variables and human use on biomass and carbon stocks of a transitional African forest: implications for forest carbon projects. Forest Ecology and Management, 351, 36-46.

Mabatuk, M. \& Wesangula, D. (2015) How sandalwood fuels lucrative illegal logging in Kenya. Http://www.standardmedia.co.ke/ lifestyle/article/2000185817/how-sandalwood-fuels-lucrative-illegallogging-in-kenya [accessed 7 January 2016].

Mitchell, N. (2004) The Exploitation and Disturbance History of Kakamega Forest, Western Kenya (eds B. Bleher \& H. Dalitz), pp. 870. University of Bielefeld, Bielefeld, Germany.

Myers, N. (1992) The Primary Source: Tropical Forests and Our Future. W.W. Norton, New York, USA.

Pfeifer, M., Lefebvre, V., Turner, E., Cusack, J., Khoo, M., Chey, V.K. \& Ewers, R.M. (2015) Deadwood biomass: an underestimated carbon stock in degraded tropical forests? Environmental Research Letters, 10, 044019.

R Development Core Team (2015) R: A Language and Environment for Statistical Computing. R Foundation for Statistical Computing, Vienna, Austria.

Travaglini, D., Barbati, A., Chirici, G., Lombardi, F., Marchetti, M. \& Corona, P. (2007) Forest BIOTA data on deadwood monitoring in Europe. Plant Biosystems, 141, 222-23O.

Tscharntke, T., Leuschner, C., Veldiamp, E., Faust, H., Guhardja, E. \& Bidin, A. (2010) Tropical rainforests and agroforests under global change: Ecological and socio-economic valuations-an introduction. In Tropical Rainforests and Agroforests under Global Change (eds T. Tsaharntke, C. Leuschner,

E. Veldkamp, H. Faust, E. Guhardja \& A. Bidin) pp. 1-11. Springer Berlin, Heidelberg, Germany.

VRŠKa, T., P̌̌ílětivý, T., Janík, D., Unar, P., Šamonil, P. \& KRÁl, K. (2015) Deadwood residence time in alluvial hardwood temperate forests-a key aspect of biodiversity conservation. Journal of Forest Ecology and Management, 357, 33-41.

W AmBUA, S.M. (2008) An economic analysis of forest extraction and its linkage to community livelihoods: The case of Kakamega rainforest. MSc thesis. University of Nairobi, Nairobi, Kenya.

\section{Biographical sketches}

Christopher Amutabi Kefa's research focuses on assessing the impacts of human use of forests on forest biodiversity. MARK LUNG has worked in Kenya for 20 years and is currently the Chief Executive Officer of Ecozlibrium. Anton Espira has conducted extensive ecology fieldwork internationally and is currently the Field Director of Ecorlibrium. ANDREW GREGORY is interested in spatial ecology, connectivity ecology and landscape genetics. The focus of his research is to understand population dynamics of non-equilibrium populations. 